which are not initially allocated to European astronomers when exclusive rights to it have expired after one year.

The SRC believes that its proposal stands a good chance of success because it would use Britain's Starlink facility which already employs highly sophisticated methods of image processing to analyse data from ground-based telescopes. The Royal Observatory in Edinburgh houses one of Starlink's six nodes. European astronomers would be able to access space telescope data quickly by travelling to Edinburgh or only slightly more slowly at one of the sites of the five other nodes, three of which are within easy reach of London, the other two being in Manchester and Cambridge. One of the main reasons for choosing Edinburgh rather than any of the five other institutes housing a node is that from next October, Dr Malcolm Longair will be director of the Edinburgh observatory. He has been closely involved in the space telescope programme since its inception.

To cope with the enormous increase in data, however, facilities at the Royal Observatory would need to be expanded, particularly by enhancing the existing image processing unit and building a special unit to cope with the data.

ESA plans to pay about $£ 66,000$ towards the capital cost of the facility, about $£ 33,000$ per year towards running costs and the salaries of seven staff. The host institution will be expected to find the rest of the cost from its own pocket.

The SRC estimates that to build the facility at Edinburgh, it would have to provide about $£ 250,000$ and pay for an extra five staff.

Judy Redfearn

\section{German workforce}

\section{Ten years on}

Microcircuits and other new technologies likely to be adopted in the 1980 s in West Germany will result in the loss of 1.8 million jobs in some low-skill sectors, and a gain of 1.9 million in other higher-skill occupations, says a new forecast commissioned by three Federal German ministries.

This massive shift in employment will require government policy "specifically shaped to counteract what will be an increasing tendency towards conflict in the community" says the report, prepared by Mackintosh Consultants Ltd of the UK and Prognos AG of Basle.

The German government has described the report as a brilliant study and awarded the teams a prize for their efforts. Mackintosh Consultants reviewed probable technical developments by making studies in the UK, Japan, Germany and the USA; and Prognos AG looked at social and economic factors, including union and management attitudes affecting their
Economically active persons classified by type of activity in FRG for 1977 and 1990 Field of activity

Economically active persons

Change: 1990

1 Mainly management functions
2 Office work
3 Entertainment, publishing
4 Education
5 Cleaning operations
6 Installation, repair and maintenance of machinery
7 Specialized consulting, R\&D
8 General supply services
9 Special supply services
10 Assemblers and assistants
11 Rail transport
12 Road and sea transport
13 Operating processing plants
14 Special tasks in manufacture of metal products
15 Special tasks in construction
16 Special tasks in food, beverages, tobacco
17 Special tasks in agriculture
18 Special tasks in mining
19 Special tasks in manufacture of clothing
20 Special tasks in printing
21 Transmission of information
22 Health services
23 Legal advice, business consultancy
24 Security functions
25 Test, measurement
26 Others
Total

(thous
1977
922
3,863
125
897
872
2,224
1,171
2,343
498
2,467
199
748
1,396
780
1,371
501
1,610
151
200
151
176
727
126
927
376
100
24,921
1990 to $1977(\%)$

introduction in the current decade. Both studies were detailed and sectional, dividing the economy into at least 50 sections and jobs into 26 categories, all of which were looked at individually (see table).

The study identified 15 sensitive sectors of the German economy where the pressure to innovate was great, but the ability to respond small. Prominent among them were the chemical industry and refineries, where the price of imported oil will require conversion to new feedstocks; but conversion will require massive investment in new capital equipment, new skills in the workforce and possibly new locations for industry to meet the distribution requirements of new raw materials.

Jobs directly connected with the introduction of the new technologies - such as installation, and the repair and maintenance of what may initially be unreliable (because untested) technologies - would increase during the 1980 s by 471,000 . But typically the qualifications required in the new jobs will be far in excess of the jobs being eliminated: spotting if a cherry is on a cake requires less education than spotting the fault in the device which detects cherries on cakes.

The area in which most jobs would be lost is in the operation of processing plants, largely through the introduction of microprocessors to handle decision-making on production lines. Here, the report estimates, there will be 396,000 fewer jobs in 1990 than there were in 1977. "Assembly", categorized separately in the study, would also lose 323,000 jobs, through reductions in numbers of components and the automatic assembly of, for example, television sets.

The Bundesministerium für Forschung und Technologie (BMFT) have estimated the range of unemployment which might follow from the Mackintosh-Prognos scenario, given different conditions of economic growth and government and industrial investment. At a pessimistic level of 2 per cent annual growth in gross national product (compared to the Mackintosh-Prognos estimate of 2.9 per cent), investment would be expected to be low, and unemployment would rise from 1.03 million this year to 2.23 million in 1985 and 2.4 million in 1990 . It would fall again to 1.44 million in 1995 , the BMFT estimate.

Mackintosh's project director for the study, Mr Tom Jacobs, said last week the likely speed of innovation would be great in the next decade but would need great social change. Hence, says the report, Germany must develop "a high level of social communication and willingness to support common objectives, which is only possible if based upon a high level of overall understanding of where the community's best interests lie. Thus, the management of social learning processes becomes a central task in politics."

Robert Walgate

\section{Environmental carcinogens}

\section{Nitrite safe?}

The US processed-meat industry received a welcome reprieve last week when the Food and Drug Administration (FDA) and the Department of Agriculture (USDA) announced that there was "insufficient evidence" to label sodium nitrite - a widely used meat preservative - a carcinogen.

Two years ago results of experiments contracted by the FDA to Dr Paul M. Newberne, Professor of Nutrition and Food Sciences at the Massachusetts 
Institute of Technology (MIT) suggested that nitrite produced cancer in the lymphatic system of laboratory rats.

Almost 13 per cent of 1,350 test animals in the study were said to have developed lymphomas, compared with only 5.75 per cent of the 573 not being fed nitrites.

The FDA had proposed a phased withdrawal of nitrites, but at the same time had announced that the MIT study was to be placed in the public record "so that the process of external scientific scrutiny can commence'. As well as gathering comments from their own scientists, the FDA and the USDA commissioned a Washington-based contract research group, Universities Associated for Research and Education in Pathology, to review the 50,000 tissue slides taken by $\mathrm{Dr}$ Newberne of his 2,000 test animals.

Last week the two agencies announced that the review of the slides revealed insufficient evidence to support $\mathrm{Dr}$ Newberne's conclusions that nitrites increased the risk of cancer in the lymphatic system. The review group said that it found fewer of the slides indicated the presence of cancer than Dr Newberne had concluded, and the agency scientists agreed.

Some of the supposed lymphomas were noncancerous, the group said, and some were histiocytic sarcomas, which have no known human counterpart.

On the basis of this reassessment of $\mathrm{Dr}$ Newberne's data, the two agencies announced that they were dropping plans to phase out the use of nitrites.

However, the statement emphasized that steps are still being taken to reduce the level of nitrites in food because of concern that, through the effects of cooking or digestion with other chemicals, nitrites can form nitrosamines, known potent carcinogens.

Following last week's announcement, the FDA has also asked the National Academy of Sciences to review and evaluate all available scientific data about nitrites, and to analyse possible alternative preservatives for use in the meat and poultry industries.

The decision not to impose a ban on nitrites was widely welcomed by food industry officials, where nitrites are used not only to prevent the spread of botulism, but also to give meat the red colouring favoured by US consumers. The industry had complained that there was no alternative agent with equivalent taste, texture and handling characteristics, and had previously claimed that a ban might destroy the US pig industry, over 70 per cent of whose products are processed with the use of nitrites.

When his research results were reported two years ago, Dr Newberne urged that they should be confirmed by other research workers before any ban was introduced. Last week he was on vacation, unable to comment on the review group's critique of his research techniques.

David Dickson
Energy conservation UK forecasts

The UK Atomic Energy Authority (UKAEA) has dismissed as "uneconomic and risky" proposals for an aggressive policy on energy conservation put forward by the International Institute for Environment and Development (IIED) 15 months ago.

That "low energy stategy" placed too much emphasis on conservation and too little on the expansion of indigenous fuel supplies say the UKAEA. Furthermore, the strategy leads to a shortfall in oil and gas supplies of up to 108 million tonnes of coal equivalent in the year 2025, say the authority, overestimates the savings possible in the domestic sector, and is inconsistent in its projections of sectional and overall economic growth.

What no doubt stuck in the authority's throat was the claim in the IIED report that electricity output can be met by building only $6 \mathrm{GW}$ of nuclear capacity in the first quarter of next century, so that nuclear power would become "a peripheral issue", and that the fast breeder "could be shelved indefinitely'. (In contrast, the UK government has since announced a $15-\mathrm{GW}$ nuclear construction programme over the decade beginning 1982.) Thus the authority wish to argue that energy demand, and particularly electricity demand, will remain more buoyant than the IIED calculate.

Gerald Leach, principal author of the IIED report, last week admitted that the low energy strategy could lead to an oil and gas shortfall in 2025, in so far as it was possible to calculate that distance into the future, but said that it would be very easy to make good the shortfall by, for example, increased coal production for which his estimate for the year 2025 had been more conservative even than the 170 million tonne target set for the year 2000 by the National Coal Board.

In domestic conservation, the level of savings depended greatly on the assumed price ratio between gas and electricity as a function of time, said Leach. "Everyone is crashing out of electricity now", and electricity prices will increase further as coal and oil become more expensive. So if cheap nuclear electricity does come on line in the UK in the 1990s it may be too late.

On the other hand, argue the UKAEA, the assumption in the low energy strategy that real incomes in 2025 will be 3 times those of today, and that electricity prices relative to gas will be 2.4 times cheaper than today, are incompatible with the assumption that domestic electricity use will decline. The greater heat gains available from electric heat pumps and their quietness, compared with gas-driven heat pumps, will lead to their preferential adoption, say the authority; and the IIED have ignored a likely trend to greater size in domestic appliances. UK refrigerators average 5-6 cubic ft, whereas American ones average 12 cubic $\mathrm{ft}$.

But potentially the most damning criticism in the UKAEA reply is that the IIED report is inconsistent. One of its most attractive conclusions was that high growth was possible alongside a reduction in energy use; but the assumed growth rate is not matched by the sectional estimates from which energy use is derived.

The IIED report, in its high growth case, assumes $2.94 \%$ annual growth in gross domestic product and the growth of nonenergy manufacturing industry at only $2.19 \%$. But that implies, the UKAEA point out, that the other sectors (which are mainly service industries) grow faster than $2.94 \%$, whereas the IIED figures show much lower growth in the measures used (for example, floor area for the commercial and institutional sector).

Leach's reply to this is that he assumes, on the basis of many interviews and studies, that the monetary productivity of a given unit in the service sector will increase. For example, the $£ / \mathrm{m}^{2}$ generated in office work will increase through the introduction of microcircuitry.

Robert Walgate

\section{Soviet space}

\section{Salyut women}

Although Soviet planners decided in 1976 not to recruit any more women to follow Valentina Tereshkova into space as a pilot, they also announced that women would still be eligible to serve aboard space stations as doctors, astronomers or stewardesses. None has yet done so but it seems as if a welcome is now being prepared aboard Salyut.

Until now, the Salyut stations have been somewhat cramped, and, according to an unattributed talk on Moscow radio last month, "quite hard and difficult even for men'. Now, however, Salyut-type stations have "more acceptable" conditions for joint work by both men and women. In the near future, stations will have separate cabins, rest rooms and showers.

Salyut 6 already has an experimental shower cabinet, in which the cosmonaut is sluiced by a stream of water drops borne by an airflow. In the future the beads of water which remain in the shower cabinet instead of passing on to the recycling system will be dealt with by the newest aid to space hygiene, a special towelling drying-bag.

One on-board luxury the would-be citizeness-cosmonaut still cannot expect is the traditional bunch of flowers on Women's Day (8 March). Soviet space biologists announced last month that they were abandoning attempts to grow flowers in space, for lack of positive results, and they were now concentrating their attention on radishes, cucumbers and carrots, which could form an important addition to the cosmonauts' diet.

Vera Rich 